\title{
Grazing-induced changes in plant composition affect litter quality and nutrient cycling in flooding Pampa grasslands
}

\author{
Lucas A. Garibaldi • María Semmartin • \\ Enrique J. Chaneton
}

Received: 4 October 2006 / Accepted: 8 November 2006 / Published online: 23 January 2007

(C) Springer-Verlag 2007

\begin{abstract}
Changes in plant community composition induced by vertebrate grazers have been found to either accelerate or slow $\mathrm{C}$ and nutrient cycling in soil. This variation may reflect the differential effects of grazing-promoted $(\mathrm{G}+)$ plant species on overall litter quality and decomposition processes. Further, site conditions associated with prior grazing history are expected to influence litter decay and nutrient turnover. We studied how grazing-induced changes in plant life forms and species identity modified the quality of litter inputs to soil, decomposition rate and nutrient release in a flooding Pampa grassland, Argentina. Litter from $\mathrm{G}+$ forbs and grasses (two species each) and grazing-reduced $(\mathrm{G}-$ ) grasses (two species) was incubated in long-term grazed and ungrazed sites. G+ species, overall, showed higher rates of decomposition and $\mathrm{N}$ and $\mathrm{P}$ release from litter. However, this pattern was primarily driven by the low-growing, high litter-quality forbs included among $\mathrm{G}+$ species. Forbs decomposed and released nutrients faster than either $\mathrm{G}+$ or $\mathrm{G}-$ grasses. While no consistent differences between $\mathrm{G}+$ and $\mathrm{G}-$ grasses were observed, patterns of grass litter decay and nutrient release corresponded with interspe-
\end{abstract}

Communicated by Alan Knapp.

L. A. Garibaldi · M. Semmartin · E. J. Chaneton

IFEVA-CONICET, Facultad de Agronomía,

Universidad de Buenos Aires, Av. San Martín 4453,

C1417DSE Buenos Aires, Argentina

L. A. Garibaldi $(\bowtie)$

Laboratorio Ecotono, Centro Regional Universitario

Bariloche, Universidad Nacional del Comahue,

Quintral 1250, 8400 Bariloche, Argentina

e-mail: garibald@agro.uba.ar cific differences in phenology and photosynthetic pathway. Litter decomposition, $\mathrm{N}$ release and soil $\mathrm{N}$ availability were higher in the grazed site, irrespective of species litter type. Our results contradict the notion that grazing, by reducing more palatable species and promoting less palatable ones, should decrease nutrient cycling from litter. Plant tissue quality and palatability may not unequivocally link patterns of grazing resistance and litter decomposability within a community, especially where grazing causes major shifts in life form composition. Thus, plant functional groups defined by species' "responses" to grazing may only partially overlap with functional groups based on species "effects" on $\mathrm{C}$ and nutrient cycling.

Keywords Decomposition · Functional groups · Herbivory $\cdot$ Mineralisation $\cdot$ Nitrogen

\section{Introduction}

Understanding the role of large herbivores in terrestrial ecosystem functioning is important from both theoretical and applied viewpoints. Nonetheless, generalisations about grazing effects on $\mathrm{C}$ and nutrient dynamics at the plant-soil interface remain elusive. Vertebrate grazers alter litter decomposition in ways that may either accelerate (Bazely and Jefferies 1985; McNaughton et al. 1997; Holland and Detling 1990; Johnson and Matchett 2001) or slow down nutrient cycling (Pastor et al. 1988, 1993; Ritchie et al. 1998; Wardle et al. 2002). Mechanisms underlying these variable impacts are potentially complex and still poorly understood, especially those associated with grazing effects on functional community composition, litter 
quality and site conditions (Bardgett et al. 1998; Bardgett and Wardle 2003).

Litter decomposition processes depend on plant tissue quality and soil environment, and large herbivores may affect both (Vossbrinck et al. 1979; Aber and Melillo 1991). Grazing-induced changes in overall litter quality may reflect short-term ecophysiological responses to herbivory (Holland and Detling 1990; Hamilton and Frank 2001), as well as longer-term shifts in plant community composition (Bardgett et al. 1998; Bardgett and Wardle 2003). At the community level, grazing alters competitive interactions and recruitment patterns, thus changing plant species abundances and life form structure (Milchunas and Lauenroth 1993). Because plant species possess different physical and chemical tissue traits, compositional changes induced by grazing will affect the average quality of plant debris entering the soil.

Empirical evidence linking plant community responses to grazing with litter quality inputs and element cycling in soil is relatively scarce and controversial. Herbivores may generally concentrate on the most palatable plants (e.g. species with high nutrient and low fibre contents), favouring dominance by least palatable species. It has been suggested that litter decomposition can be governed by similar tissue traits as those determining plant palatability to herbivores (Pastor et al. 1993; Grime et al. 1996; Cornelissen et al. 1999). Accordingly, one would expect grazing-induced plant replacements to result in low-quality litter inputs to soil and a reduction of decomposition rates. Studies supporting this mechanism have focused on moose browsing in boreal forests (Pastor et al. 1988, 1993), white-tailed deer in oak savannas (Ritchie et al. 1998), voles in riparian meadows (Sirotnak and Huntly 2000), introduced deer and goats in New Zealand forests (Wardle et al. 2002), and domestic cattle in semi-arid grasslands (Moretto et al. 2001).

In contrast, other studies have shown that herbivores can promote species producing high-quality litter at the expense of species with low litter quality (Belovsky and Slade 2000; Olofsson and Oksanen 2002). Such compositional shifts will tend to enhance decomposition and nutrient release from litter. In a tundra heath ecosystem, Olofsson and Oksanen (2002) found that reindeer grazing increased high tissue-quality grasses, whose litter decomposed faster than that produced by shrubs dominating in lightly grazed areas. In comparing rangelands along a moisture gradient, Semmartin et al. (2004) reported that differences in nutrient release rates observed between the litter derived from grazing-promoted $(\mathrm{G}+)$ and grazing-susceptible (grazing-reduced; $\left.\mathrm{G}_{-}\right)$species were habitat-specific. $\mathrm{G}+$ species from a mesic grassland showed higher nutrient contents and release rates than their $\mathrm{G}$ - counterparts. Yet, the reverse pattern was true for semi-arid and xeric grasslands (Semmartin et al. 2004).

Overall, there appears to be conflicting evidence for a general model of grazing effects on nutrient cycling based on the premise that plant traits conferring herbivory resistance also control litter decomposability (Grime et al. 1996; Bardgett and Wardle 2003). Current models for vegetation-soil decomposer feedbacks driven by grazing assume that resistance to herbivory is largely dictated by species palatability and regrowth ability upon defoliation (De Mazancourt and Loreau 2000; Bardgett and Wardle 2003). Models predict that functional groups derived from species' "responses" to grazing will correspond with those defined by species "effects" on ecosystem processes such as decomposition (see Lavorel et al. 1997; Díaz and Cabido 2001; Lavorel and Garnier 2002). If not, grazing should have no consistent impact (positive or negative) on nutrient cycling through plant species turnover. However, the match between both types of functional groupings may be imperfect (Lavorel and Garnier 2002), because other traits allowing grazing avoidance like short stature, prostrate growth habit or a fugitive regeneration strategy (Díaz et al. 2001) may be of little relevance to plant species effects on $\mathrm{C}$ and nutrient cycling.

Grazing can also affect site conditions for litter turnover through long-term changes in the soil environment. Vertebrate herbivores influence soil properties via direct effects such as trampling and urine/dung deposition, or through indirect pathways associated with changes in plant productivity and floristic composition (Milchunas and Lauenroth 1993; Bardgett and Wardle 2003; Sankaran and Augustine 2004). Soil abiotic conditions including temperature, bulk density and water content (Takar et al. 1990; Fahnestock and Knapp 1994), as well as soil decomposer biomass and activity (Stark and Grellmann 2002; Patra et al. 2004; Sankaran and Augustine 2004), may all be affected by grazing. Moreover, heavy grazing on temperate grasslands has been found to switch the soil microbial community from a fungi-dominated system to a bacteria-dominated one (Bardgett et al. 1996). However, field studies linking plant community turnover with litter decay processes across sites differing in prior grazing history are still lacking (but see Olofsson and Oksanen 2002).

In this study we focus on grazing-induced shifts in plant life form composition and species identity within life forms to examine how domestic herbivores alter litter decomposition and nutrient cycling in a flooding Pampa grassland, Argentina. Our objectives were: (1) 
to evaluate the dynamics of litter mass loss and nutrient $(\mathrm{N}, \mathrm{P})$ release for $\mathrm{G}+$ versus $\mathrm{G}-$ species, and (2) to examine whether patterns of nutrient turnover in the litter differ between sites with contrasting grazing histories. Plant community changes due to domestic grazing have been extensively documented in the flooding Pampa (Sala et al. 1986; Facelli 1988; Rusch and Oesterheld 1997; Chaneton et al. 2002). Tall tussock grasses dominate in lightly grazed or protected areas, while they are replaced by low-growing, broad-leaved forbs and prostrate grasses under continuous grazing. We hypothesised that such changes in life form composition would impact on nutrient cycling through changes in litter quality and decay processes. Indeed, $\mathrm{N}$ and $\mathrm{P}$ budgets for grazed and ungrazed areas show that cattle grazing accelerates nutrient cycling in this system (Chaneton et al. 1996), but the putative mechanisms have not been tested in field experiments.

Here we characterise the litter chemistry and decomposition dynamics of several grassland species that were grown in a common garden. The litter included species from three major "response" functional groups (Díaz and Cabido 2001; Lavorel and Garnier 2002), defined a priori according with the species' life form and known response to grazing. Specifically, we considered $\mathrm{G}+$ grasses, $\mathrm{G}+$ forbs and $\mathrm{G}-$ grasses ( $\mathrm{G}-$ forbs do not occur in our system), and asked whether significant differences exist in their "effects" on decomposition and nutrient turnover. In addition, we evaluated changes in litter decay mediated by the soil environment, by incubating litter from plants grown in a common garden in two grassland sites with contrasting grazing histories, which originally belonged to the same plant community type. In each site, the established vegetation was removed to distinguish soil environmental effects on decomposition from those associated with canopy microclimate.

\section{Materials and methods}

\section{Study area}

The plant collection and decomposition experiment were conducted in a humid prairie located near Pila, $\sim 200 \mathrm{~km}$ south of Buenos Aires, at the centre of the flooding Pampa in eastern Argentina $\left(36^{\circ} 30^{\prime} \mathrm{S}\right.$, $\left.58^{\circ} 30^{\prime} \mathrm{W}\right)$. The climate is temperate subhumid, with mean monthly temperatures ranging from $7^{\circ} \mathrm{C}$ in July to $22^{\circ} \mathrm{C}$ in January. Mean annual precipitation is $990 \mathrm{~mm}$, being distributed throughout the year with peaks in autumn and spring. The landscape is characterised by an extremely flat topography and treeless physiognomy. Soils are Typic Natraquolls, with a 15cm-deep loamy A horizon $(\mathrm{pH}=6.7)$ containing $3.5 \%$ organic $\mathrm{C}$ and $24 \%$ clay, and a thick natric B horizon. The area undergoes periodic floods of varied magnitude, mainly from autumn through late spring (Lavado and Taboada 1988). The site has been continuously grazed by domestic cattle for ca. 100 years and has never been ploughed.

The vegetation corresponds to the most widespread community type in the central flooding Pampa (Perelman et al. 2001) and comprises a mix of dicotyledonous forbs and $\mathrm{C}_{3}$ and $\mathrm{C}_{4}$ graminoids. At the study site, relative forb cover varies from up to $30 \%$ in grazed areas, to less than $1 \%$ in ungrazed areas (Rusch and Oesterheld 1997; Chaneton et al. 2002). Grazing also promotes $\mathrm{C}_{4}$ prostrate grasses, while it reduces the cover of $\mathrm{C}_{3}$ tussock grasses (Facelli 1988; Chaneton et al. 2002). Aerial net primary productivity may reach $\sim 500 \mathrm{~g} \mathrm{~m}^{-2}$ year $^{-1}$ in ungrazed sites but tends to decrease under continuous grazing (Rusch and Oesterheld 1997). In grazed sites, more than $50 \%$ of total $\mathrm{N}$ and $\mathrm{P}$ located in aboveground biomass occurs in broadleaved forbs (Chaneton et al. 1996).

\section{Experimental design}

We used aerial litter from two species selected from each of three major functional groups (Table 1, hereafter named only by genus). Species were chosen based on their relative contribution to the cover of each functional group and the consistency of their individual responses to grazing, as determined from long-term exclosure experiments in the study grassland (Chaneton et al. 1988, 2002; Rusch and Oesterheld 1997). Our plant groupings thus reflect both the direct (preference-mediated) and indirect (e.g. competition-mediated) effects of grazing on species abundances (see Díaz et al. 2001). Species selected among G+ forbs, $G+$ grasses and $\mathrm{G}-$ grasses contributed 85,82 and $35 \%$ of the overall functional group cover, respectively (Semmartin et al. 2007). Naturalised, exotic species were also included as appropriate (Table 1) since they are an integral component of the system showing clear-cut responses to grazing (Sala et al. 1986; Chaneton et al. 2002).

During July-September 2001 (mid winter-early spring), individual plants of each species were collected from a grassland subject to continuous grazing and then cultured in a common garden at the College of Agronomy campus in Buenos Aires, where climatic conditions are similar to those at the field site. This procedure allowed us to collect standing dead material (leaves and stems) produced by $\mathrm{G}+$ and $\mathrm{G}-$ species 
Table 1 Grazing-promoted $(\mathrm{G}+)$ and grazing-reduced $(\mathrm{G}-)$ plant species used in the litterbag decomposition experiments

\begin{tabular}{|c|c|c|c|c|c|c|}
\hline & \multirow[t]{2}{*}{ Life form } & \multirow[t]{2}{*}{ Growth habit } & \multirow[t]{2}{*}{ Peak growth } & \multirow[t]{2}{*}{ Life history } & \multicolumn{2}{|c|}{ Relative cover $(\%)^{\mathrm{a}}$} \\
\hline & & & & & Grazed & Ungrazed \\
\hline \multicolumn{7}{|l|}{$\mathrm{G}+$ species $^{\mathrm{b}}$} \\
\hline Leontodon taraxacoides ${ }^{\mathrm{c}}$ & Forb, $\mathrm{C}_{3}$ & Rosette & Spring & Perennial & 13.5 & 0.02 \\
\hline Aster squamatus & Forb, $\mathrm{C}_{3}$ & Leafy erect & Summer & Perennial & 0.32 & 0.01 \\
\hline Panicum gouinii & Grass, $\mathrm{C}_{4}$ & Semi-prostrate & Spring-summer & Perennial & 6.8 & 0.3 \\
\hline $\begin{array}{l}\text { Stenotaphrum secundatum } \\
\text { G- species }\end{array}$ & Grass, $\mathrm{C}_{4}$ & Prostrate & Summer & Perennial & 30.2 & 0.01 \\
\hline Lolium multiflorum $^{\mathrm{c}}$ & Grass, $\mathrm{C}_{3}$ & Erect & Spring & Annual & 8.1 & 48.0 \\
\hline Paspalum dilatatum & Grass, $\mathrm{C}_{4}$ & Semi-prostrate & Summer & Perennial & 2.5 & 3.3 \\
\hline
\end{tabular}

${ }^{a}$ Mean relative basal cover of species in each study site for the period 1985-2004 (data from Chaneton et al. 2002; Semmartin et al. 2007)

b Species' responses to grazing determined from comparisons of grazed and ungrazed (exclosure) sites, after Chaneton et al. (1988, 2002), Facelli (1988), Rusch and Oesterheld (1997)

c Exotic species

over a 5-month period. By using litter produced by plants grown under common conditions, we were also able to minimise any short-term effects on litter quality associated with recent defoliation events. The litter was air dried and cut into 2-cm-long pieces to grossly simulate physical breakdown by cattle trampling and comminution by soil fauna (Seastedt 1984). Litterbags $\left(60 \mathrm{~cm}^{2}\right)$ were made of $0.35-\mathrm{mm}$-mesh nylon fabric and were filled with $1 \mathrm{~g}$ of air-dry litter. While we recognise that the small mesh size could reduce access to soil fauna (Seastedt 1984; Bradford et al. 2002), it helped to prevent excessive loss of material, particularly forb leaf litter, during bag manipulation.

Litterbags were incubated in two nearby locations within the same paddock: (1) a continuously grazed site (stocking rate 0.55 cow ha $^{-1}$ year $^{-1}$ ), and (2) a 18-yearold, 4-ha ungrazed site (exclosure). In the grazed site, the experiment comprised two main factors, litter type (six species and a plastic litter control) and incubation period (46, 89 and 155 days), with five replicate litterbags per treatment. In the ungrazed site, we incubated a sub-set of three species (Leontodon, Lolium and Paspalum; Table 1) to allow for the influence of site conditions associated with grazing history, as well as possible interactions between litter type and decomposition site. The design for the ungrazed site also comprised the litter type (three species and a plastic litter control) and incubation period (same as in grazed site) as main factors $(n=5)$. Plastic "litter" controls were included to: (1) evaluate whether decomposition of different litter species changed soil $\mathrm{N}$ content relative to background levels of soil $\mathrm{N}$ availability (measured under plastic litter bags), and (2) test for inter-site differences in soil $\mathrm{N}$ availability in the absence of plant litter effects.

Within each site, litter types and extraction dates were randomly assigned to incubation cores arranged in a $36-\mathrm{m}^{2}$ grid. In the grazed site the experiment was protected by adding a steel cage closed at the top. Litterbags were placed on the soil surface and individually enclosed by an open-ended PVC tube $(15 \mathrm{~cm}$ diameter, $20 \mathrm{~cm}$ height) sunk to $18 \mathrm{~cm}$ depth. Two months before the experiment, all aboveground vegetation surrounding the incubation tubes was removed by herbicide application (glyphosate at $0.6 \mathrm{~g} \mathrm{~m}^{-2}$ ). This manipulation "homogenised" the grazed and ungrazed sites with respect to canopy-associated conditions for decomposition. Glyphosate effects on soil properties are usually negligible or may entail a slight stimulation of soil microbial activity (Busse et al. 2001). Residual effects of glyphosate can be discarded because it suffers rapid degradation or immobilisation in clayed soils (Busse et al. 2001; Araújo et al. 2003). Plants growing inside the cores were weeded by hand on a weekly basis. The PVC tubes combined with frequent weeding prevented nutrient loss to plant uptake, a potential source of error for net mineralisation estimates based on field incubations (Hart et al. 1994). The incubation period spanned from 4 February to 9 July 2002 (i.e. mid summer through early winter). During the study, timing of seasonal flooding and daily temperatures were typical for the area, although flood intensity was greater than usual. Cumulative rainfall during the experiment was $744 \mathrm{~mm}$, or $66 \%$ above average $(447 \pm 130 \mathrm{~mm}$, last 45 years). In mid March 2002, the study area became flooded and remained so until the end of the experiment. Both the grazed and ungrazed sites were similarly waterlogged with $5-10 \mathrm{~cm}$ standing water.

Plant litter and soil analyses

Initial concentrations of $\mathrm{N}, \mathrm{P}$, cell solubles, celluloses (cellulose + hemicellulose) and lignin were determined 
for each litter type $(n=3)$. For $\mathrm{N}$ and $\mathrm{P}$ determinations, $100 \mathrm{mg}$ of milled litter was digested using a standard Kjeldahl procedure. Digests were analysed colorimetrically in a flow-injection autoanalyser (Alpkem, Wilsonville, Oreg.). The analysis of fibre fractions was based on 500-mg aliquots of milled samples and was performed following the protocol described by Van Soest et al. (1991).

Decomposition dynamics were characterised by the litter mass remaining (percentage of initial mass) inside the bags at each extraction date. The remnant litter was gently brushed and washed to remove soil particles, dried to constant weight and weighed. Ash corrections were technically impossible as remaining mass was used for $\mathrm{N}$ and $\mathrm{P}$ determinations (see below) in advanced litterbag harvests. Litter decomposition rates were estimated by calculating the decay constant $k$, as the slope of a single exponential model for each combination of litter type and site (Wieder and Lang 1982): $\ln \left(M_{t} / M_{0}\right)=y-k t$, where $M_{0}$ and $M_{t}$ represent the initial litter mass and the mass remaining at time $t$ (in years), respectively. The $k$ values were obtained by least-squares regression using all replicates per litter type for each date.

To evaluate $\mathrm{N}$ and $\mathrm{P}$ dynamics in the litter we calculated: (1) the amount of $\mathrm{N}$ and $\mathrm{P}$ released during decomposition, and (2) the mineral $\mathrm{N}$ content of the soil beneath the litterbags. $\mathrm{N}$ and $\mathrm{P}$ contents in remnant litter were calculated as the remaining mass $\times$ nutrient concentration for each harvest date, and were expressed as percentages of the initial $\mathrm{N}$ and $\mathrm{P}$ contents. Nutrient concentrations were determined as described above for the initial litter. On day 0 and day 46 of incubation, the soil beneath each litterbag was sampled to $5 \mathrm{~cm}$ depth. Soil $\mathrm{NH}_{4}^{+}$and $\mathrm{NO}_{3}^{-}$concentrations were determined colorimetrically (Alpkem) after extracting a $10-\mathrm{g}$ subsample with $50 \mathrm{ml}$ of $2 \mathrm{~mol} \mathrm{l}^{-1} \mathrm{KCl}$.

\section{Statistical analyses}

To test for grazing effects mediated by floristic replacements we focused on differences between $\mathrm{G}+$ and $\mathrm{G}-$ species incubated at the grazed site. Principal component analysis (PCA) was performed on the initial litter $\mathrm{N}$, $\mathrm{P}$, cell solubles, celluloses and lignin concentrations to obtain a synthetic index of interspecific differences in litter chemistry. The PCA matrix included 6 species $\times 5$ litter traits. Univariate patterns in litter chemistry were analysed through one-way ANOVA with litter species as main factor (six levels), followed by several a priori contrasts: (1) G+ vs. G- species, (2) forbs versus grasses, (3) $G+$ versus $G-$ grasses, (4)
forbs-Leontodon versus Aster, (5) G+ grasses-Panicum versus Stenotaphrum, and (6) G- grassesLolium versus Paspalum. All contrasts were orthogonal, except for contrast (1) with respect to (2) and (3). Litter mass loss and changes in $\mathrm{N}$ and $\mathrm{P}$ contents during decomposition were examined through two-way ANOVAs, with litter type (six levels) and incubation period (three levels) as main factors. The same contrasts as described above were performed to determine significant differences across life forms and species. Changes in soil $\mathrm{N}$ availability beneath the various litter types at 46 days of incubation were evaluated by oneway ANOVA (treatment contrasts as described above).

To test whether decomposition and nutrient release from litter differed with the site grazing history, we focused on the three litter species incubated in both the grazed and ungrazed sites. For changes in litter mass and $\mathrm{N}$ and $\mathrm{P}$ contents over time, we used threeway ANOVAs with species (three levels), incubation period (three levels) and incubation site (two levels: grazed vs. ungrazed) as main factors. Patterns in soil mineral $\mathrm{N}$ were analysed using two-way ANOVA, with litter type (five levels: three species and the plastic controls at 0 and 46 days) and incubation site (two levels). Since vegetation surrounding the incubation cores was removed and microclimatic conditions (i.e. temperature and light levels) for litterbags were likely to be the same in both sites, we interpreted any potential site effect as the influence of local soil environment (biotic or abiotic) on decomposition (objective 2). Functional relationships between initial litter chemistry, decay rates and soil $\mathrm{N}$ levels were examined through simple correlation analysis $(n=9$, both sites taken together).

It must be noted that analyses testing for site effects used replicate litterbags and soil samples constrained to one grazed and one ungrazed area. Hence, our experiment was pseudoreplicated for statistically inferring grazing effects through site history (Hurlbert 1984). Nevertheless, by drawing from previous knowledge of the system, we surmise that inter-site differences may be chiefly attributed to prior grazing history. First, both sites shared the same topography, soil type, plant community, and grazing regime before the exclosure was established in 1983 (Rusch and Oesterheld 1997). Second, we are not aware of any factor, except for grazing history, which had differentially affected the two sites over the last 20 years. Finally, spatial dependence of several soil properties within each site was found to level-off at scales much smaller than those implicit in our inter-site comparison (Lavado et al. 1996). 


\section{Results}

The first PCA axis (PCA-1) explained $80 \%$ of the variance in initial litter chemistry and, overall, discriminated between the forb and grass litter types (Table 2). Forb species had positive PCA scores while the two $\mathrm{C}_{4}$ grasses, Stenotaphrum $(\mathrm{G}+)$ and Paspalum (G-), showed the highest negative scores. Panicum $\left(\mathrm{G}+, \mathrm{C}_{4}\right)$ and Lolium $\left(\mathrm{G}-, \mathrm{C}_{3}\right)$ had medium scores. Litter N, P, cell solubles and lignin contents increased (loadings: $0.45,0.45,0.47$ and 0.38 , respectively), whereas celluloses decreased (loading: 0.48) along PCA-1. Initial litter chemistry significantly differed between $\mathrm{G}+$ and $\mathrm{G}-$ species. On average, $\mathrm{G}+$ species had higher $\mathrm{N}, \mathrm{P}$, cell solubles and lignin concentrations, and lower celluloses concentrations, than $\mathrm{G}-$ species (Tables 2, 3). However, G+ and $\mathrm{G}-$ grasses did not significantly differ in initial litter chemistry (Tables 2, 3). Forbs had greater $\mathrm{N}, \mathrm{P}$, cell solubles and lignin concentrations, but lower celluloses concentrations, than all grass species taken together.

Litter decomposition dynamics differed significantly among species in the grazed site $\left(F_{5,72}=102\right.$, $P<0.0001 ;$ Fig. 1a). The litter remaining after 5 months of incubation ranged from 11 to $54 \%$ of the initial mass. On average, $\mathrm{G}+$ species decomposed faster than $\mathrm{G}-$ species $\left(F_{1,72}=46.5, P<0.0001\right)$ irrespective of incubation time (Fig. 1a). However, this pattern was largely accounted for by the forb species, which decomposed more rapidly than any of the grasses regardless of their specific response to grazing $\left(F_{1,72}=349, P<0.0001\right.$; Table 4$)$. While $\mathrm{G}+$ grasses tended to decompose more slowly than $\mathrm{G}-$ grasses $\left(F_{1,72}=8.5, P=0.005\right)$, there were substantial differences within the $\mathrm{G}+\left(F_{1,72}=7.5, P<0.01\right)$ and the $\mathrm{G}-$ $\left(F_{1,72}=140, P<0.0001\right)$ grass response groups. Lolium (G-) had the fastest decomposition rate, Panicum $(\mathrm{G}+)$ was intermediate, and the $\mathrm{C}_{4}$ grasses Stenotaphrum $(\mathrm{G}+)$ and Paspalum $(\mathrm{G}-)$ were the slowest decomposing species (Table 4, Fig. 1a).

The species ranking for decay rates of the common litter types was the same in both the grazed and ungrazed sites, with highly significant differences among the three species tested $\left(F_{2,71}=296, P<0.0001\right.$; Fig. 1b). In general, however, rates of litter mass loss were lower in the ungrazed than in the grazed site $\left(F_{1,71}=38.4, P<0.0001\right.$; Table 4$)$. Lolium decomposition was greatly reduced when placed in the ungrazed site, but the other litter types were less affected by the incubation site (species $\times$ site, $F_{2,71}=5.8, P=0.005$; Table 4).

Nutrient turnover during decomposition significantly differed among species in the grazed site $(\mathrm{N}$, $F_{5,72}=263, \quad P<0.0001 ; \quad \mathrm{P}, \quad F_{5,72}=104, \quad P<0.0001$; Fig. 2a). Litter $\mathrm{N}$ and $\mathrm{P}$ varied between 200 and $10 \%$ relative to initial contents, reflecting periods of net
Table 2 Initial litter chemistry of $\mathrm{G}+$ and $\mathrm{G}-$ species. Values are means with SEs in parentheses $(n=3)$. PCA $1=$ Species scores on first axis of principal component analysis including all chemical variables, Solubles $=$ soluble fraction of carbohydrates, Celluloses $=$ cellulose and hemicellulose; for other abbreviations, see Table 1

\begin{tabular}{|c|c|c|c|c|c|c|}
\hline & PCA 1 & $\% \mathrm{~N}$ & $\% \mathrm{P}$ & \%Solubles & $\%$ Celluloses & \%Lignin \\
\hline \multicolumn{7}{|l|}{$\mathrm{G}+$ species } \\
\hline Aster & $3.4(0.3)$ & $1.82(0.14)$ & $0.130(0.014)$ & $65(3.8)$ & $24(2.6)$ & $11(1.0)$ \\
\hline Leontodon & $1.5(0.5)$ & $1.08(0.17)$ & $0.092(0.009)$ & $55(1.7)$ & $35(1.1)$ & $10(1.6)$ \\
\hline Panicum & $-0.8(0.2)$ & $1.07(0.13)$ & $0.072(0.001)$ & $27(2.9)$ & $66(1.9)$ & $6(0.7)$ \\
\hline Stenotaphrum & $-1.3(0.4)$ & $0.83(0.06)$ & $0.062(0.016)$ & $21(0.7)$ & $71(1.1)$ & $5(1.1)$ \\
\hline \multicolumn{7}{|l|}{$\mathrm{G}-$ species } \\
\hline Lolium & $-1.0(0.5)$ & $0.88(0.17)$ & $0.076(0.017)$ & $31(0.2)$ & $64(0.7)$ & $3(0.4)$ \\
\hline Paspalum & $-1.9(0.2)$ & $0.64(0.04)$ & $0.046(0.009)$ & $25(0.8)$ & $70(1.3)$ & $5(0.5)$ \\
\hline
\end{tabular}

Table 3 Summary of statistical contrasts ${ }^{\mathrm{a}}$ ( $F$-values) for initial differences in litter chemistry. For abbreviations, see Tables 1 and 2

\begin{tabular}{|c|c|c|c|c|c|c|}
\hline Species contrast & PCA 1 & $\mathrm{~N}$ & $\mathrm{P}$ & Solubles & Celluloses & Lignin \\
\hline $\mathrm{G}+$ vs. $\mathrm{G}-$ species & $48.1 * * *$ & $15.8 * *$ & $7.1 *$ & $61.2 * * *$ & $173.7 * * *$ & $14.5^{* *}$ \\
\hline Forbs vs. grasses & $140.8^{* * *}$ & $29.1 * * *$ & $19.8 * * *$ & $357.9 * * *$ & $784.6 * * *$ & $16.9 * *$ \\
\hline $\mathrm{G}+$ grasses vs. $\mathrm{G}-$ grasses & 1.3 & 2.2 & 0.2 & 3.6 & 0.9 & 4.1 \\
\hline Forbs: Leontodon vs. Aster & $13.5 * *$ & $16.8 * *$ & 4.7 & $9.9^{* *}$ & 20.9 *** & 0.3 \\
\hline G+ grasses: Panicum vs. Stenotaphrum & 1.2 & 1.8 & 0.3 & 4.3 & $5.3 *$ & 0.3 \\
\hline G- grasses: Lolium vs. Paspalum & 3.6 & 1.8 & 3.1 & 4.4 & $7.2 *$ & 0.0 \\
\hline
\end{tabular}

$* P<0.05, * * P<0.01, * * * P<0.001$

a $d f$ for all contrasts $=1,12$ 

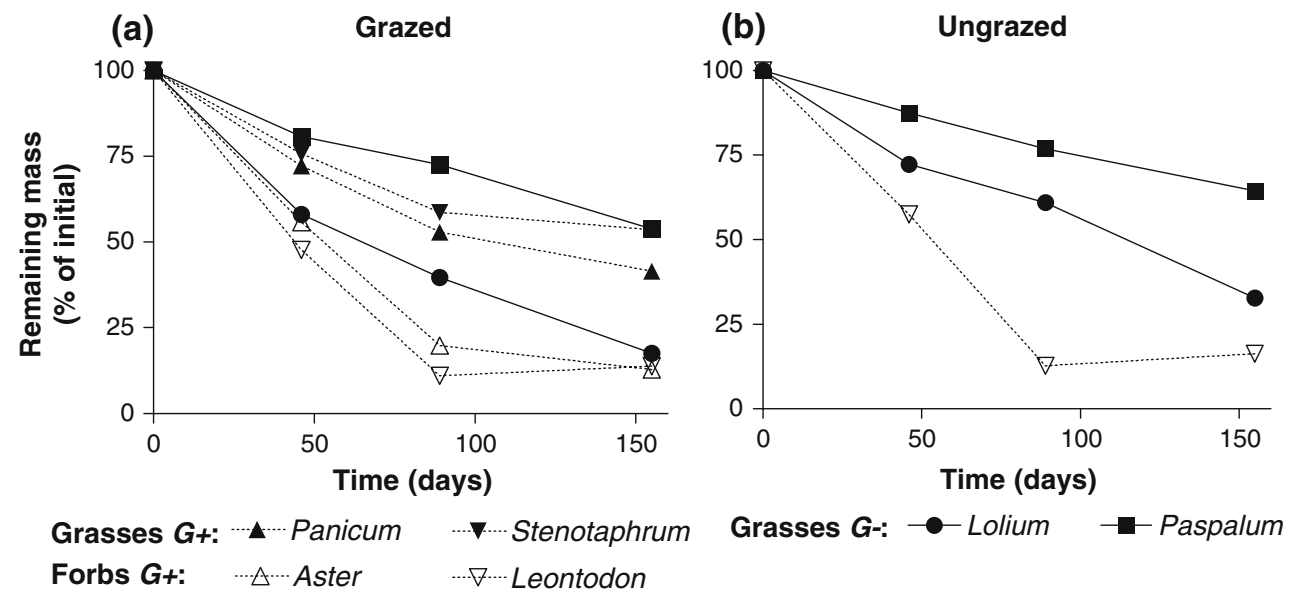

Fig. 1 Litter mass loss for grazing-promoted $(\mathrm{G}+$, broken lines) and grazing-reduced $(\mathrm{G}-$, solid lines) species grown in a common garden, decomposing in a grazed and $\mathbf{b}$ ungrazed grassland where

vegetation has been removed. Values are means of five replicate litterbags (error bars omitted for clarity; see text for statistical results)

Table 4 Litter decay constant $\left(k\right.$, year $\left.{ }^{-1}\right)$ estimated by least squares regression ${ }^{\mathrm{a}}$ for $\mathrm{G}+$ and $\mathrm{G}-$ species in the grazed and ungrazed sites. SEs are shown in parentheses. For other abbreviations, see Table 1

\begin{tabular}{llllll}
\hline & \multicolumn{2}{l}{ Grazed } & & \multicolumn{2}{l}{ Ungrazed } \\
\cline { 2 - 3 } & $k$ & $r^{2}$ & & $r^{2}$ \\
\hline G+ species & & & & \\
Leontodon & $5.2(0.8)$ & 0.70 & & $5.0(0.7)$ & 0.76 \\
Aster & $5.3(0.6)$ & 0.81 & & \\
Panicum & $2.1(0.2)$ & 0.90 & & \\
Stenotaphrum & $1.5(0.2)$ & 0.84 & & \\
G- species & & & & \\
Lolium & $4.1(0.3)$ & 0.94 & $2.7(0.3)$ & 0.86 \\
Paspalum & $1.5(0.2)$ & 0.72 & $1.1(0.1)$ & 0.90 \\
\hline
\end{tabular}

a All regressions were significant at $P<0.0001$

immobilisation and mineralisation, respectively. Taken together, $\mathrm{G}+$ species released more $\mathrm{N}\left(F_{1,72}=368\right.$, $P<0.0001)$ and more $\mathrm{P}\left(F_{1,72}=141, P<0.0001\right)$ during litter breakdown than $\mathrm{G}-$ species, regardless of incubation time (Fig. 2a). Again, this pattern was primarily determined by differences between forbs and grasses. After 3 months of incubation, forb species had released 6 times more $\mathrm{N}$ and 8 times more $\mathrm{P}$ than the grasses $(\mathrm{N}$, $\left.F_{1,72}=795, P<0.0001 ; \mathrm{P}, F_{1,72}=333, P<0.0001\right)$. Forb species did not differ from each other in $\mathrm{N}$ and $\mathrm{P}$ dynamics (Fig. 2a). On average, $\mathrm{G}+$ grasses released $\mathrm{N}$ and $\mathrm{P}$ faster than $\mathrm{G}-$ grasses $\left(\mathrm{N}, F_{1,72}=34.4\right.$, $\left.P<0.0001 ; \mathrm{P}, F_{1,72}=10.0, P=0.002\right)$. However, nutrient release dynamics were highly idiosyncratic within each grass response group. Whereas the litter of Lolium (G-) and Panicum $(\mathrm{G}+)$ tended to release $\mathrm{N}$ and $\mathrm{P}$ with increasing incubation time, that of Paspalum $(\mathrm{G}-)$ and Stenotaphrum $(\mathrm{G}+)$ immobilised both nutrients throughout the study period (Fig. 2a).

In the ungrazed site, interspecific differences in litter $\mathrm{N}$ and $\mathrm{P}$ release were similar to those found in the grazed site $\left(F_{2,72}=421, P<0.0001\right.$; Fig. $\left.2 b\right)$. However, the litter of species incubated in the ungrazed site released on average $25 \%$ less $\mathrm{N}$ than their counterparts in the grazed site (site, $F_{1,72}=8.3, \quad P=0.005$; species $\times$ site, $\left.F_{1,72}=2.6, P=0.08\right)$. Site effects on $\mathrm{P}$ release were rather variable, and depended on the species and incubation time (three-way interaction: $F_{4,71}=4.0, P=0.006$ ). As a general trend, during the first 46 days of study, litter released more $P$ when placed in the ungrazed than in the grazed site. Yet, for the remaining of the experiment the opposite was true, and litter released more $\mathrm{P}$ in the grazed than in the ungrazed site.

Soil mineral $\mathrm{N}$ levels beneath the litterbags were significantly higher in the grazed than in the ungrazed grassland, both at the outset and after 46 days of experiment $\left(F_{1,50}=26.1, P<0.0001\right.$; Fig. 3$)$, but did not differ among the four litter types (three species and plastic litter) incubated in both sites $\left(F_{4.50}=1.3, P=0.3\right.$; site $\times$ litter type, $\left.F_{4,50}=1.1, P=0.4\right)$. Soil $\mathrm{N}$ availability after 46 days of incubation also did not significantly differ beneath the six species incubated within the grazed site $\left(F_{5,24}=1.3, P=0.3\right)$.

Species scores on PCA axis 1 and initial litter N, P, cell solubles and lignin contents were positively correlated with the decay constant $k$ (Table 5). In contrast, litter celluloses concentrations, and the amounts of $\mathrm{N}$ and $\mathrm{P}$ retained in the litter after 89 days of incubation, were all negatively correlated with $k$. Among the litter traits studied here, initial cell solubles and celluloses showed the highest correlation with $k$ (Table 5). Soil mineral $\mathrm{N}$ showed no significant correlation with initial litter traits or $k$. 

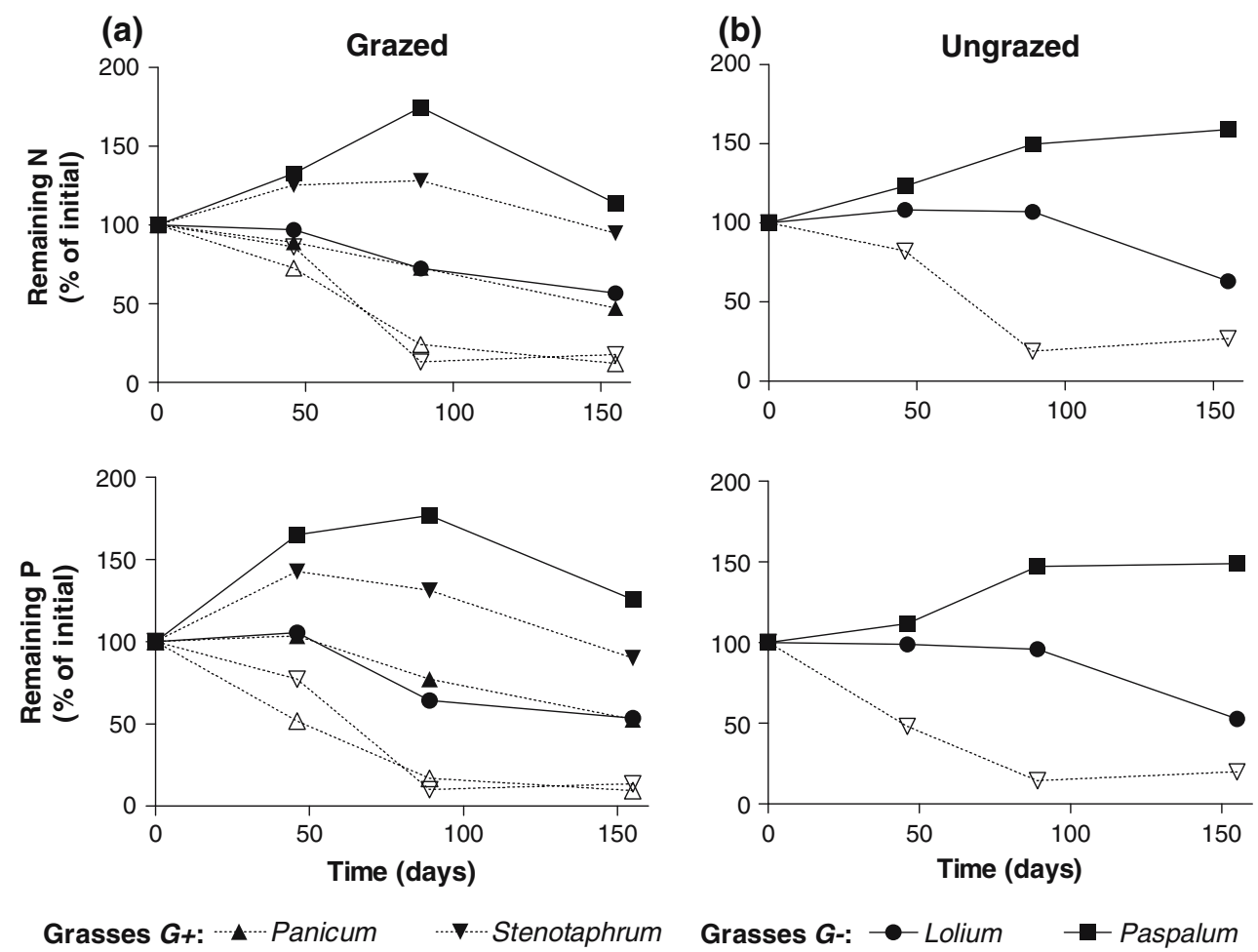

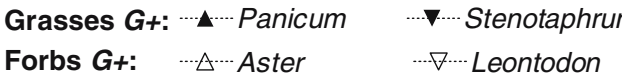

Fig. 2 Changes in litter $\mathrm{N}$ and $\mathrm{P}$ contents for $\mathrm{G}+$ (broken lines) and $\mathrm{G}-$ (solid lines) species grown in a common garden, decomposing in $\mathbf{a}$ grazed and $\mathbf{b}$ ungrazed grassland where vegetation has been removed. Values are means of five replicate litterbags (error bars omitted for clarity; see text for statistical results). For abbreviations, see Fig. 1

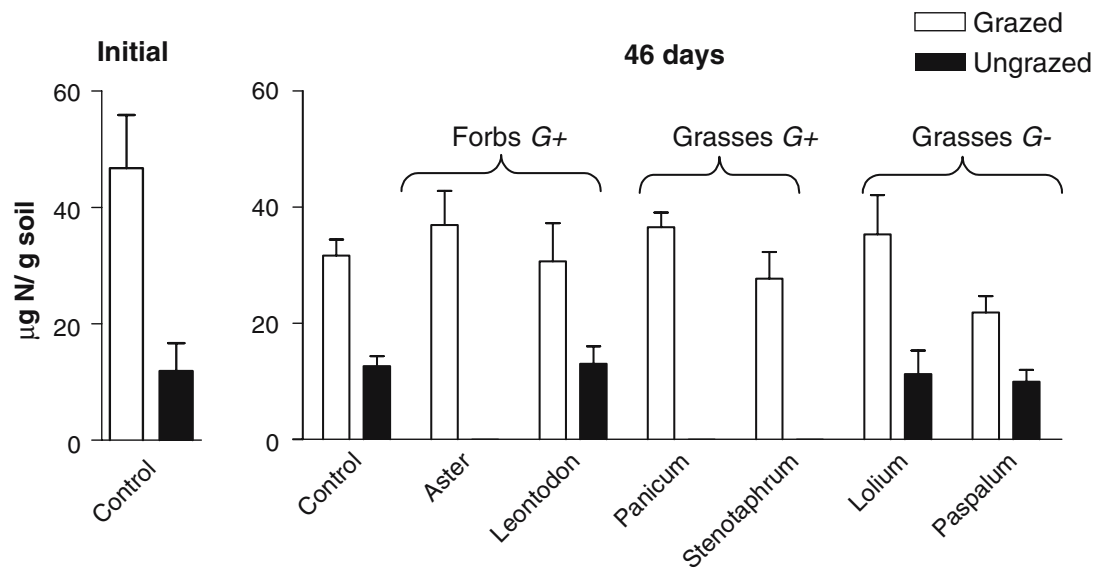

Fig. 3 Total soil mineral $\mathrm{N}\left(\mathrm{NH}_{4}^{+}+\mathrm{NO}_{3}^{-}\right)$beneath litterbags of $\mathrm{G}+$ and $\mathrm{G}-$ species grown in a common garden, placed in the grazed (open bars) and ungrazed (shaded bars) grassland where vegetation has been removed. The control treatment refers to

\section{Discussion}

We found evidence consistent with the hypothesis that grazing-induced changes in grassland composition enhance decomposition and nutrient release from litter. In our case, G+ species comprised two forbs producing high quality litter, which also decomposed bags filled with plastic "litter". Data were taken at the start of the experiment (left panel, non-flooded soil) and after 46 days of incubation (right panel, flooded soil). Values are means $+1 \mathrm{SE}$ $(n=5)$. For abbreviations, see Fig. 1

faster and released more nutrients than any of the grass species studied. We did not find consistent differences in litter quality or decay processes that could be related with the grass species' responses to grazing. Thus, grazing may exert an indirect influence on ecosystem function by accelerating nutrient cycling through the increased quality of litter inputs to soil associated with 
Table 5 Correlation coefficients (Pearson's $r)^{\text {a }}$ between initial litter chemistry and summary variables of litter decay dynamics. $N 89=$ Litter $\mathrm{N}$ contents (\%) after 89 days of incubation, $P 89=$

litter P contents (\%) after 89 days of incubation; for other abbreviations, see Tables 2 and 4

\begin{tabular}{|c|c|c|c|c|c|c|c|c|}
\hline & PCA 1 & $\mathrm{~N}$ & $\mathrm{P}$ & Solubles & Celluloses & Lignin & $k$ & N89 \\
\hline$k\left(\right.$ year $\left.^{-1}\right)$ & 0.89 & 0.72 & 0.88 & 0.92 & -0.91 & 0.70 & & \\
\hline $\mathrm{N} 89(\%)^{\mathrm{a}}$ & -0.88 & -0.75 & -0.85 & -0.86 & 0.87 & -0.74 & -0.92 & \\
\hline P89 (\%) & -0.88 & -0.75 & -0.86 & -0.87 & 0.87 & -0.71 & -0.94 & \\
\hline Soil $\mathbf{N}\left(\mu \mathrm{g} \mathrm{N} \mathrm{g}{ }^{-1}\right.$ soil $\left.^{-1}\right)$ & 0.34 & 0.52 & 0.47 & 0.20 & -0.22 & 0.22 & 0.33 & -0.39 \\
\hline
\end{tabular}

${ }^{\text {a }}$ All values significant at $P<0.05$, less those for soil $\mathrm{N}$

changes in life form composition. In addition, decomposition, nutrient release and soil available $\mathrm{N}$ were all higher in the grazed grassland, suggesting that grazers may further accelerate element cycling through longterm changes in soil conditions. However, we did not assess how litter from the same species grown in the two grazing sites might decompose differently in their respective sites because litter was obtained from plants grown in a common garden.

Functional effects derived from plant species replacements were associated with a shift in the grassland life form structure. Livestock grazing markedly increases forb species colonisation in the study system (Sala et al. 1986; Rusch and Oesterheld 1997; Chaneton et al. 2002). Forb litter decomposed and released nutrients much faster than the litter produced by $\mathrm{G}+$ and $\mathrm{G}-$ grasses, which agrees with published work on broader-scale comparisons of litter quality and decomposability across species and life forms (e.g. Cornelissen 1996; Cornelissen et al. 1999; Wardle et al. 2002). Therefore, our findings could be relevant to other grassland ecosystems where large grazers promote broad-leaved forbs while decreasing grass species cover (Milchunas and Lauenroth 1993; McIntyre and Lavorel 2001; Johnson and Matchett 2001; Olofsson and Oksanen 2002).

We found species-specific differences in litter quality and decay processes among grasses, but these "effects" were idiosyncratic between species within each grazing "response" group. Grass litter decomposition and nutrient turnover appeared to depend on the species' phenology and photosynthetic pathway. Winter-spring grasses (Lolium and Panicum) showed faster decomposition and nutrient turnover than summer grass species (Stenotaphrum and Paspalum). These results are consistent with the notion that $\mathrm{C}_{4}$ grasses may posses lower tissue quality, decomposition and nutrient release rates than $\mathrm{C}_{3}$ grasses (Kemp et al. 1994; Murphy et al. 2002). Attributes like low tissue $\mathrm{N}$ and high fibre contents are thought to reflect the adaptation of $\mathrm{C}_{4}$ grasses to conditions of frequent nutrient and water shortages in habitats with extended warm seasons
(Ehleringer and Monson 1993), which are common in the central flooding Pampas (Soriano 1992).

Litter decomposition and nutrient release rates correlated with initial litter attributes as summarised by the first PCA axis. Concentration of cell solubles and celluloses had the highest correlation with decomposition; the higher cell solubles and the lower celluloses in the litter, the higher the decomposition rate. In contrast, initial lignin content was positively correlated with decomposition rate, and there was no significant relationship between lignin:nutrient ratios and decomposition or nutrient release (data not shown; Aber and Melillo 1991). Forb species exhibited the highest lignin concentrations and litter decay dynamics but the lowest celluloses concentrations. Thus, although lignin is one of the most recalcitrant components of cell walls, differences in total celluloses and cell solubles were more relevant to predict differences in litter decomposability across species within the time-frame of this study (Pastor et al. 1993; Semmartin et al. 2004). The lignin content may become a better predictor of decomposition rates in later stages of the decay process (Aber and Melillo 1991). Different components of the cell wall can play different roles in regulating soil microbial activity and should receive more attention in comparative studies. More generally, these results highlight the difficulty in predicting "hard" functional attributes of plants (Walker and Langridge 2002), that is, measurable species effects on ecosystem processes such as decomposition or nutrient cycling, from "soft" functional attributes inferred from tissue traits such as lignin and $\mathrm{N}$ content, which are often assumed to influence soil processes in a given direction.

Litter decomposition and $\mathrm{N}$ release were generally greater in the grazed grassland. Grazing effects on decomposition environment mediated by altered canopy structure could not be tested in this study because plant cover was removed from both study sites. Further, our results were unlikely to reflect any lasting side effects from the herbicide on soil nutrient dynamics (Busse et al. 2001; Araújo et al. 2003). Indeed, mean levels of soil mineral $\mathrm{N}$ were similar to those reported 
before for this grassland $\left(33.7-44.2 \mu \mathrm{g} \mathrm{N} \mathrm{g}^{-1}\right.$ soil $^{-1}$; Chaneton et al. 1996). On the other hand, the increased rates of litter turnover in the grazed site might reflect the fact that all species were collected from that same site. Yet we think this is hardly the case. In another experiment, we reciprocally incubated litter produced by Lolium and Paspalum plants taken from both the grazed and ungrazed sites, and found no significant origin $\times$ site interaction on decomposition and nutrient release rates (Semmartin et al. unpublished). This finding indicates that changes in decay processes between sites cannot be attributed to the "adaptation" of the local soil biota to degrading litter produced by formerly grazed plants. Rather, our results point towards an independent effect of the soil incubation environment on litter dynamics.

While mechanisms underlying site effects are beyond the scope of this study, we hypothesise that inter-site differences could reflect changes in the soil environment for decomposition induced by long-term removal of grazing. It has been shown that grazing can stimulate soil microbial activity in various ways (Bardgett et al. 1998; Patra et al. 2004). For example, dung and urine deposition by grazers represent a source of readily available $\mathrm{C}$ and $\mathrm{N}$ to soil microbes, which often enhances litter degradation and nutrient turnover (Bazely and Jefferies 1985; Ruess and McNaughton 1987). Nutrient cycling from animal excreta, coupled with changes in plant composition, may both contribute to increase soil nutrient availability (Chaneton et al. 1996), creating a positive plant-soil feedback in grazed areas (Bardgett and Wardle 2003). This is consistent with the greater mineral $\mathrm{N}$ levels found in grazed than in ungrazed soil, irrespective of flooding conditions (Fig. 3). Previous work in the system also showed greater mineral $\mathrm{N}$ levels, and a 30 $50 \%$ higher plant nutrient uptake that corresponded with enhanced mineralisation rates in grazed grassland (Chaneton et al. 1996).

Interspecific differences in nutrient release dynamics did not translate into significant changes in soil $\mathrm{N}$ availability associated with different litter species during this study. One likely explanation is that flooding increased denitrification losses, and also probably resulted in the fine-scale horizontal movement of dissolved nutrients within each site. Both these processes could reduce the potential effects of litter amendments on measured soil mineral $\mathrm{N}$ pools. Most importantly, however, flooding did not change the pattern of litter turnover across the different litter types (Figs. 1, 2). Relative treatment differences observed up to the first harvest, both within each site and between the grazed and ungrazed sites, remained essentially the same after the onset of the flooding. Our study does, however, weight results towards those that may occur during flooded periods, since litterbags were not flooded for only $30 \%$ of the incubation time.

Overall, our results do not conform with predictions that grazing-induced changes in community composition will reduce litter quality, decomposition rates and nutrient cycling. It has been proposed that litter decomposition and species palatability to herbivores may be governed by similar plant traits (Pastor et al. 1993; Grime et al. 1996; Cornelissen et al. 1999; Wardle et al. 2002). Hence, herbivores that selectively consume more palatable species and favour the dominance of less palatable ones with poor litter quality should lower decomposition and mineralisation rates at the community level (Bardgett et al. 1998). This hypothesis has gained support in various systems (Pastor et al. 1988, 1993; Ritchie et al. 1998; Sirotnak and Huntly 2000; Moretto et al. 2001; Wardle et al. 2002). Here, we observed the opposite trend, with litter from $\mathrm{G}+$ species showing, on average, higher quality and faster decomposition and nutrient release rates than the litter produced by $\mathrm{G}-$ species. These results concur with those of Olofsson and Oksanen (2002), who showed that reindeer grazing promoted grasses of high litter quality, which decomposed faster than dominant shrubs from lightly grazed sites. In both studies, positive feedbacks between grazing effects on community composition and litter decomposition were associated with plant replacements at the life form level.

The contrasting feedback patterns observed in different systems may be related with the nature of plant traits conferring resistance to grazing. Models that seek to explain negative feedbacks between grazing and soil nutrient cycling through plant species turnover assume that resistance to herbivory is largely dictated by tissue palatability (see Bardgett et al. 1998; Bardgett and Wardle 2003). However, in systems where positive feedbacks dominate, this assumption might not be met, and other grazing resistance mechanisms such as avoidance through prostrate growth habits (Milchunas et al. 1988; Díaz et al. 2001) or tolerance via compensatory growth (De Mazancourt and Loreau 2000), may be of greater relevance. In the flooding Pampa, low palatability does not appear to be the key attribute allowing $\mathrm{G}+$ species to thrive under heavy grazing. The $\mathrm{G}+$ forbs and grasses included in our study avoid biomass loss to large grazers based on their low-growing habits (Facelli 1988), or by recruiting seedlings in canopy gaps (Oesterheld and Sala 1990; Insausti et al. 1995). We thus suggest that where plant resistance to grazing is not solely based on reduced palatability, G+ species as a whole will not necessarily 
exhibit lower litter quality and decomposition rates than co-occurring $\mathrm{G}$ - species.

The existence of feedbacks (either positive or negative) between grazing effects on community composition and soil nutrient cycling would suggest a close correspondence between "response" and "effect" plant functional groups (Lavorel et al. 1997; Díaz and Cabido 2001). While we studied a small, though representative, subset of species for the study grassland, our results suggest that predicting species effects on ecosystem processes on the basis of their response to certain environmental drivers (e.g. grazing) may not be straightforward (Lavorel and Garnier 2002). Functional groups derived a priori from species' responses to grazing $(\mathrm{G}+$ vs. $\mathrm{G}-$ ) only partially overlapped with measured species effects on litter turnover dynamics (see also Walker and Langridge 2002). Only when coarse, grazing-induced shifts in life form composition were considered, did functional response and effect groups coincide. Yet, grass species effects on litter decay processes did not clearly co-vary with their known resistance to grazing. This supports the view that tight correlations between functional response and effect groups should not always be expected, and may depend on the level of taxonomic resolution and the environmental factor being considered (Lavorel and Garnier 2002).

In summary, our study contributes to a better understanding of mechanisms involved in plant-soil feedbacks driven by grazing impacts on vegetation composition. Effects of environmental forces (grazing, fire, drought, etc.) mediated by plant species turnover are of general interest for predicting functional changes in ecosystems. A close link between attributes determining plant responses to a given environmental factor and those affecting key ecosystem processes has often been assumed, but theory and data show that this is not always the case (Lavorel and Garnier 2002; Walker and Langridge 2002). In grazed systems, partial matching between "response" and "effect" functional groups would imply a greater heterogeneity of litter inputs to soil and nutrient cycling, as G+ species may either accelerate or decelerate litter turnover in local patches. This spatial aspect of functional diversity within a plant community (Elmqvist et al. 2003) may contribute to enhance ecosystem resilience in the long term.

Acknowledgements We thank the Bordeu family for kindly permitting us to work on their property. P. Ocariz, M. Oyarzábal, D. Saravia, M. Dondo and the Gates family helped us at various stages. T. Seidler and three anonymous reviewers contributed valuable comments on the manuscript. This study was supported by grants from Agencia Nacional de Promoción Científica y
Tecnológica (PICTs 6761 and 13940) and University of Buenos Aires (G-413) M. S. was partly supported by Fundación Antorchas and René Baron fellowships.

\section{References}

Aber JD, Melillo JM (1991) Litter decomposition and nutrient balances. In: Terrestrial ecosystems. Saunders College Publishing, Philadelphia, Pa., pp 173-192

Araújo ASF, Monteiro RTR, Abarkeli RB (2003) Effect of glyphosate on the microbial activity of two Brazilian soils. Chemosphere 52:799-804

Bardgett RD, Wardle DA (2003) Herbivore-mediated linkages between aboveground and belowground communities. Ecology 84:2258-2268

Bardgett RD, Hobbs PJ, Frostegard A (1996) Changes in fungal:bacterial biomass ratios following reductions in the intensity of management on an upland grassland. Biol Fertil Soils 22:261-264

Bardgett RD, Wardle DA, Yeates GW (1998) Linking aboveground and below-ground interactions: how plant responses to foliar herbivory influence soil organisms. Soil Biol Biochem 30:1867-1878

Bazely DR, Jefferies RL (1985) Goose faeces: a source of nitrogen for plant growth in a grazed salt marsh. J Appl Ecol 22:693-703

Belovsky GE, Slade JB (2000) Insect herbivory accelerates nutrient cycling and increases plant production. Proc Natl Acad Sci USA 97:14412-14417

Bradford MA, Tordoff GM, Eggers T, Jones TH, Newington JE (2002) Microbiota, fauna, and mesh size interactions in litter decomposition. Oikos 99:317-323

Busse MD, Ratcliff AW, Shestak CJ, Powers RF (2001) Glyphosate toxicity and the effects of long-term vegetation control on soil microbial communities. Soil Biol Biochem 33:1777-1789

Chaneton EJ, Facelli JM, León RJC (1988) Floristic changes induced by flooding on grazed and ungrazed lowland grasslands in Argentina. J Range Manage 41:495-499

Chaneton EJ, Lemcoff JH, Lavado RS (1996) Nitrogen and phosphorus cycling in grazed and ungrazed plots in a temperate subhumid grassland in Argentina. J Appl Ecol 33:291-302

Chaneton EJ, Perelman SB, Omacini M, León RJC (2002) Grazing, environmental heterogeneity, and alien plant invasions in temperate Pampa grasslands. Biol Inv 4:7-24

Cornelissen JHC (1996) An experimental comparison of leaf decomposition rates in a wide range of temperate plant species and types. J Ecol 84:573-582

Cornelissen JHC, Perez-Harguindeguy N, Díaz S, Grime JP, Marzano B, Cabido M, Vendramini F, Cerabolini B (1999) Leaf structure and defence control litter decomposition rate across species and life forms in regional floras on two continents. New Phytol 143:191-200

De Mazancourt C, Loreau M (2000) Effect of herbivory and plant species replacement on primary production. Am Nat 155:735-754

Díaz S, Cabido M (2001) Vive la différence: plant functional diversity matters to ecosystem processes. Trends Ecol Evol 16:646-655

Díaz S, Noy-Meir I, Cabido M (2001) Can grazing response of herbaceous plants be predicted from simple vegetative traits? J Appl Ecol 38:497-508

Ehleringer JR, Monson RK (1993) Evolutionary and ecological aspects of photosynthetic pathway variation. Annu Rev Ecol Syst 24:411-439 
Elmqvist T, Folke C, Nyström M, Peterson G, Bengtsson J, Walker B, Norberg J (2003) Response diversity, ecosystem change, and resilience. Front Ecol Environ 1:488-494

Facelli JM (1988) Response to grazing after nine years of cattle exclusion in a flooding Pampa grassland, Argentina. Vegetatio $78: 21-25$

Fahnestock JT, Knapp AK (1994) Plant responses to selective grazing by bison-interactions between light, herbivory and water stress. Vegetatio 115:123-131

Grime JP, Cornelissen JHC, Thompson K, Hodgson JG (1996) Evidence of a causal connection between anti-herbivore defence and the decomposition rate of leaves. Oikos 77:489494

Hamilton EW, Frank DA (2001) Can plants stimulate soil microbes and their own nutrient supply? Evidence from a grazing tolerant grass. Ecology 82:2397-2402

Hart CH, Stark JM, Davidson EA, Firestone MK (1994) Nitrogen mineralisation, immobilization and nitrification. In: Methods of soil analysis. Part 2. Microbiological and biochemical properties. Soil Science of America, book series no. 5

Holland EA, Detling J (1990) Plant response to herbivory and belowground nitrogen cycling. Ecology 71:1040-1049

Hurlbert SH (1984) Pseudoreplication and the design of ecological field experiment. Ecol Monogr 54:187-211

Insausti P, Soriano A, Sanchez RA (1995) Effect of flood-induced factors on seed germination of Ambrosia tenuifolia. Oecologia 103:127-132

Johnson LC, Matchett JR (2001) Fire and grazing regulate belowground processes in tall grass prairie. Ecology 82:3377-3389

Kemp PR, Waldecker DG, Owensby CE, Reynolds JF, Virginia RA (1994) Effects of elevated $\mathrm{CO}_{2}$ and nitrogen fertilization pretreatments on decomposition and tallgrass prairie leaf litter. Plant Soil 165:115-127

Lavado RS, Taboada MA (1988) Water, salt and sodium dynamics in a Natraquoll in Argentina. Catena 15:577-594

Lavado RS, Sierra JO, Hashimoto PN (1996) Impact of grazing on soil nutrients in a Pampean grassland. J Range Manage 49:452-457

Lavorel S, Garnier E (2002) Predicting changes in community composition and ecosystem functioning from plants traits: revisiting the Holy Grail. Funct Ecol 16:545-556

Lavorel S, McIntye S, Landsber J, Forbes TDA (1997) Plant functional classifications: from general groups to specific groups based on response to disturbance. Trends Ecol Evol 12:474478

McIntyre S, Lavorel S (2001) Livestock grazing in subtropical pastures: steps in the analysis of attribute response and plant functional types. J Ecol 89:209-226

McNaughton SJ, Banyikwa FF, McNaughton MM (1997) Promotion of the cycling of diet-enhancing nutrients by African grazers. Nature 278:1798-1800

Milchunas DG, Lauenroth WK (1993) Quantitative effects of grazing on vegetation and soils over a global range of environments. Ecol Monogr 63:327-366

Milchunas DG, Sala OE, Lauenroth WK (1988) A generalized model of the effects of grazing by large herbivores on grassland community structure. Am Nat 132:87-106

Moretto AS, Distel RA, Didoné NG (2001) Decomposition and nutrient dynamic of leaf litter and roots from palatable and unpalatable grasses in a semi-arid grassland. Appl Soil Ecol 18:31-37

Murphy KL, Burke IC, Vinton MA, Lauenroth WK, Aguiar MR, Wedin DA, Virginia RA, Lowe PN (2002) Regional analysis of litter quality in the central grassland region of North America. J Veg Sci 13:395-402
Oesterheld M, Sala OE (1990) Effects of grazing on seedling establishment: the role of seed and safe-site availability. J Veg Sci 1:353-358

Olofsson J, Oksanen L (2002) Role of litter decomposition for the increased primary production in areas heavily grazed by reindeer: a litterbag experiment. Oikos 96:507-515

Pastor J, Naiman RJ, Dewey B, McInnes P (1988) Moose, microbes, and the boreal forest: through selective browsing, moose change plant communities and ecosystem properties. BioScience 38:770-777

Pastor J, Dewey B, Naiman RJ, NcInnes PF, Cohen Y (1993) Moose browsing and soil fertility in the boreal forests of Isle Royale National Park. Ecology 74:467-480

Patra AK, Abbadie L, Clays-Josserand A, Degrange V, Grayston SJ, Loiseau P, Louault F, Mahmood S, Nazaret S, Philippot L, Poly F, Prosser JI, Richaume A, Le Roux X (2004) Effects of grazing on microbial functional groups involved in soil dynamics. Ecol Monogr 75:65-80

Perelman SB, León RJC, Oesterheld M (2001) Cross-scale vegetation patterns of Flooding Pampa grasslands. J Ecol 89:562577

Ritchie ME, Tilman D, Knops JMH (1998) Herbivore effects on plant and nitrogen dynamics in oak savannah. Ecology 79:165-177

Ruess WR, McNaughton SJ (1987) Grazing and the dynamics of nutrient and energy regulated microbial processes in the Serengeti grasslands. Oikos 49:101-110

Rusch GM, Oesterheld M (1997) Relationship between productivity, and species and functional group diversity in grazed and non-grazed Pampas grassland. Oikos 78:519-526

Sala OE, Oesterheld M, León RJC, Soriano A (1986) Grazing effects upon plant community structure in subhumid grasslands of Argentina. Vegetatio 67:27-32

Sankaran M, Augustine DJ (2004) Large herbivores supress decomposer abundance in a semi-arid grazing ecosystem. Ecology 85:1052-1061

Seastedt TR (1984) The role of microarthropods in decomposition and mineralisation processes. Annu Rev Entomol 29:25-46

Semmartin M, Aguiar M, Distel RA, Moretto A, Ghersa CM (2004) Litter quality and nutrient cycling affected by grazinginduced species replacements along a precipitation gradient. Oikos 107:148-160

Semmartin M, Oyarzábal M, Loreti J, Oesterheld M (2007) Controls of primary productivity and nutrient cycling in a temperate grassland with year-round production. Aust Ecol (in press)

Sirotnak JM, Huntly NJ (2000) Direct and indirect effects of herbivores on nitrogen dynamics: voles in riparian areas. Ecology 81:78-87

Soriano A (1992) Río de la Plata grasslands. In: Coupland RT (ed) Ecosystems of the World, vol 8 A, Natural Grasslands. Elsevier, Amsterdam, pp 367-407

Stark S, Grellmann D (2002) Soil microbial responses to herbivory in an arctic tundra heath at two levels of nutrient availability. Ecology 83:2736-2744

Takar AA, Dobrowlski JP, Thurow TL (1990) Influence of grazing, vegetation life-form, and soil type on infiltration rates and inter-rill erosion on Somalian rangeland. J Range Manage 43:486-490

Van Soest PJ, Robertson JB, Lewis BA (1991) Carbohydrate methodology, metabolism, and nutritional implications in dairy cattle. J Dairy Sci 74:3583-3597

Vossbrinck CR, Coleman DC, Woolley TA (1979) Abiotic and biotic factors in litter decomposition in a semiarid grassland. Ecology 60:265-271 
Walker HB, Langridge JL (2002) Measuring functional diversity in plant communities with mixed life forms: a problem of hard and soft attributes. Ecosystems 5:529-538

Wardle DA, Bonner KI, Barker GM (2002) Linkages between plant litter decomposition, litter quality, and vegetation responses to herbivores. Funct Ecol 16:585-595
Wieder RK, Lang GE (1982) A critique of the analytical methods used in examining decomposition data obtained from litter bags. Ecology 63:1636-1642 